\title{
CONSTITUTIONAL RETROGRESSION IN INDONESIA UNDER PRESIDENT JOKO WIDODO'S GOVERNMENT: What CAN THE CONSTITUTIONAL COURT DO?
}

\author{
Abdurrachman Satrio* \\ Center for State Policy Studies, Faculty of Law University of Padjadjaran \\ Imam Bonjol No. 21, Bandung 40132 \\ abdurrachmanmarley@gmail.com
}

\begin{abstract}
This paper examines whether constitutional retrogression, the process through which democratically elected rulers use formal legal measures gradually to undermine democracy, has occurred in Indonesia, especially during the reign of President Joko Widodo. To this end, the paper analyzes the impact of the Widodo government's policies on three fundamental requirements of a democratic state: a democratic electoral system, rights to speech and association, and the rule of law. The paper finds that Widodo's government, in its efforts to contain the threat of Islamist populism, has indeed undermined all three of these elements to varying degrees. While Indonesia's democracy may yet be saved by the Constitutional Court, an institution that Widodo's government has until now failed to control, the Court cannot save democracy by itself. Its chances of doing so will depend on public support.
\end{abstract}

Keywords: Constitutional Court, Constitutional Retrogression, Democracy, Joko Widodo, Indonesian.

* Researcher at the Center for State Policy Studies, Faculty of Law Padjadjaran University.

This article was previously presented at the 2nd Indonesian Constitutional Court International Symposium on the "Constitutional Court and Constitutionalism in Political Dynamics", Yogyakarta, 1-3 October 2018. I wish to thank Theunis Roux, for his invaluable suggestions and corrections that have helped me to develop this article, and also Bjoern Dressel for his helpful comments. 


\section{INTRODUCTION}

The most important issue in comparative constitutional law right now is how constitutions may be designed and used to protect democratic order. This issue has become important because of the massive recent decline in democratic quality around the world. This phenomenon is occurring not only in newly established democratic countries but also in seemingly stable democracies. ${ }^{1}$ According to Freedom House, democracy is facing "its most serious crisis in the decade".

What makes this phenomenon so disturbing for comparative constitutional scholars is not the number of countries that are degrading the quality of democracy, but the way they are doing so. ${ }^{3}$ In contrast to authoritarian rulers of the past, who seized power and demolished democracy blatantly using non-juridical mechanisms such as military coups or by using emergency power mechanisms, the new generation of rulers is destroying democracy using constitutional mechanisms. Typically, they gain power through democratic elections, then destroy democracy using lawful measures provided for in the constitution. ${ }^{4}$

The use of legal mechanisms to destroy democracy is manifest through actions such as silencing the opposition using existing criminal law provisions rather than extrajudicial acts; establishing a neutral-looking electoral law under the guise of creating political stability, but in fact undermining the opposition's ability to win the next election;5 or launching legal reforms that weaken the ability of other institutions to impose checks on executive power. ${ }^{6}$ There are now numerous studies of this phenomenon, ${ }^{7}$ with scholars using a variety of different

\footnotetext{
Examples of countries that passed through the transition period and then experienced a decline in democratic quality are Poland, Russia, and Turkey. An example of a stable democracy that has recently experienced democratic decline is the United States, especially after the 2016 Presidential Election. See Aziz Huq and Tom Ginsburg, "How to Lose a Constitution al Democracy", UCLA Law Review 65, (forthcoming 2018).

2 "Freedom in the World 2018 Democracy in Crisis," Freedom House, accessed 3 July 2018, https://freedomhouse. org/report/freedom-world/freedom-world-2018.

Kim Lane Scheppele, "Autocratic Legalism," The University of Chicago Law Review 85 (2018): 547.

Ozan Varol, "Stealth Authoritarianism," lowa Law Review 100 (2015): 1677.

Ibid, 1679 .

Scheppele, "Autocratic Legalism", 547.

Many studies about this phenomenon are listed at https://www.democratic-decay.org, a resource created by comparative constitutional law scholar, Tom Gerald Daly, focusing on studying the global trend toward incremental deterioration of democratic governance without any abrupt or clear breakdown of the democratic system.
} 
labels to describe it, including 'autocratic legalism,, 'abusive constitutionalism,', 'stealth authoritarianism'10 and 'constitutional retrogression'." For the purposes of this essay, I will use the latter term, as defined by Aziz Huq and Tom Ginsburg.

The central question that this paper asks is whether this phenomenon is also occurring in Indonesia. Twenty years after the reformasi - the series of democratic amendments to the 1945 Constitution that liberated Indonesia from Suharto's authoritarian New Order regime ${ }^{12}$ - the quality of Indonesia's democracy, once hailed as the most stable in Southeast Asia, ${ }^{13}$ is clearly deteriorating, especially in the era of President Joko Widodo's government. ${ }^{14}$ Earlier this year, for example, the Economist's Intelligence Unit reported Indonesia's democracy index as experiencing its most significant decline over the last 10 years. ${ }^{15}$ In order to examine whether this decline fits the pattern of constitutional retrogression, this paper analyzes whether the actions of President Joko Widodo's government have compromised three fundamental elements that are necessary to the proper functioning of a democratic state: (1) a democratic electoral system; (2) rights to speech and association; and (3) the rule of law. ${ }^{16}$ The paper's central argument is that these three elements are indeed being compromised, not because Widodo's government is directly opposed to them, but because the way it has chosen to

\footnotetext{
Scheppele, "Autocratic Legalism."

David Landau, "Abusive Constitutionalism," UC Davis Law Review 189 (2013).

Varol, "Stealth Authoritarianism".

Huq and Ginsburg, "How to Lose a Constitutional Democracy," UCLA Law Review 65 (2018).

12 Susi Dwi Harijanti and Tim Lindsey, "Indonesian general election tests the amended Constitution and the new Constitutional Court", International Journal of Constitutional Law 4, no. 1 (2006), 138.

13 Marcus Mietzner views Indonesian democracy as the most stable in Southeast Asia because, after the fall of Soeharto, Indonesia successfully established a functioning electoral democracy, stabilized its economy, ended a series of communal conflicts, and even settled the decades-old separatist conflict in Aceh through negotiations. Marcus Mietzner, "Political Conflict Resolution and Democratic Consolidation in Indonesia: The Role of the Constitutional Court," Journal of East Asian Studies 10 (2010): 397.

14 Edward Aspinall, "Twenty Years of Indonesian Democracy - How Many More?" New Mandala, accessed 24 May 2018, http://www.newmandala.org/20-years-reformasi/.

15 This survey gives a score of 6.39 for the Indonesian democracy index in 2017, compared with the previous year's score of 6.97. This decline is the most significant decline in Indonesia's democracy index since this survey was introduced in 2006. See "The Economist Intelligence Unit's Democracy Index," The Economist. accessed 5 July 2018, https://infographics.economist.com/2018/Democracylndex/.

16 Democracy, as Tom Daly notes, is a contested concept. This is why some countries, like Hungary and Poland, refer respectively to "illiberal democracy" and "conservative democracy", but still lay claim to being a constitutional democracy. However, in this essay, I choose not to give democracy a narrow interpretation that only requires elections, but like Huq and Ginsburg, broadly understand it as requiring rights to speech and association, neutral legal institutions, and elections. Without the first two elements, competitive elections cannot be implemented. See Huq and Ginsburg, "How to Lose a," 8. See also Tom Gerald Daly, "Democratic Decay in 2016," in Annual Review of Constitution-Building Processes, ed. International IDEA(Stockholm: International IDEA, 2016), 10-11.
} 
respond to the anti-democratic Islamic populist movement in Indonesia has indirectly compromised them. In particular, it is argued that, under the guise of protecting democracy from the threat of Islamic populism, Joko Widodo's government has used a repressive and coercive approach that has had exactly the opposite effect. ${ }^{17}$

After setting out this argument, the paper moves to examine the role of the Constitutional Court in protecting Indonesia's democracy from constitutional retrogression. The main reason why this paper gives the Constitutional Court a spotlight to play that role was that until now Widodo's government still fail to capture the Constitutional Court, apart from that, the experience of other countries also shown that constitutional courts may be able to play a role in this respect. In Colombia, the Constitutional Court famously stopped President Alvaro Uribe's attempt to amend the Constitution to allow him to run for a third term. ${ }^{18}$ Such examples illustrate that strong constitutional courts may be able in certain circumstances to compensate for weaknesses in constitutional design. ${ }^{19}$

The other reason to focus on the Constitutional Court as the main defence against constitutional retrogression is that countries that recently transitioned from authoritarianism to democracy, like Indonesia, established their constitutional courts precisely for this purpose. ${ }^{20}$ Indeed, in many of these countries, the Constitutional Court is considered more democratic than political institutions, such as the executive and legislature, which in theory have stronger claims to democratic legitimacy. ${ }^{21}$

17 Marcus Mietzner, "Fighting Illiberalism with Illiberalism: Islamic Populist and Democratic Deconsolidation in Indonesia," Pacific Affairs 21, no. 2 (2018).

18 Landau, "Abusive Constitutionalism."

19 Much constitutional designs to protect democracy like electoral system, opposition rights, amendment mechanism, and also the constitutional court often fail against the attempt to harm democracy through the use of a constitutional mechanism like an example in the Hungary and Poland. Dieter Grimm, "How can a democratic constitution survive an autocratic majority?" Verfassungblog, accessed 14 December 2018, https://verfassungsblog. de/how-can-a-democratic-constitution-survive-an-autocratic-majority/.

20 Renata Uitz, "Constitutional Courts in Central and Eastern Europe: What Makes a Question too Political?" Juridica International XIII (2007): 50.

${ }^{21}$ Kim Lane Scheppele, "Democracy by Judiciary. Or, why Courts Can be More Democratic than Parliaments," in Rethinking the Rule of Law after Communism, ed. Adam Czarnota, Martin Krygier and Wojciech Sadurski (Budapest: Central European University Press, 2005). 


\section{ANALYSIS}

\subsection{Explaining Constitutional Retrogression}

Many terms have been used to describe the phenomenon where a ruler uses the constitution and laws to destroy democracy, including 'abusive constitutionalism', 'autocratic legalism', and 'constitutional retrogression'. This paper will use the term 'constitutional retrogression', as coined by Aziz Huq and Tom Ginsburg, for several reasons.

First, the term 'abusive constitutionalism', which was developed by David Landau, focuses attention on attempts to destroy democracy by using mechanisms of constitutional change, such as amendment or replacement, as exemplified in Venezuela and Colombia.. ${ }^{22}$ However, democracy may be destroyed without such mechanisms, as demonstrated in Poland. ${ }^{23}$ In contrast, 'constitutional retrogression' focuses on actions to destroy democracy more broadly.

Second, while the 'constitutional retrogression' concept is not completely different from the idea of 'autocratic legalism' developed by Kim Lane Scheppele, constitutional retrogression establishes three definite benchmarks to assess whether a government action destroys democracy or not. ${ }^{24}$ These benchmarks, according to Huq and Ginsburg, consist of elements that must exist in every democratic government, namely: (1) a democratic electoral system; (2) rights to speech and association; and (3) integrity of law and legal institutions, i.e., the rule of law. ${ }^{25}$

22 Landau, "Abusive Constitutionalism."

${ }_{23}$ In Poland, the ruling Law and Justice Party were unable to undermine democracy through the amendment mechanism as it did not possess the required two-thirds majority in Parliament. However, it was still able to undermine democracy by using laws whose substance weakened other institutions set up to check executive powers, such as the Constitutional Court and the Ombudsman. See Gabor Halmai, "Second Grade Constitutionalism? Hungary and Poland: How the EU Can and Should Cope with Illiberal Member States," in Developments in Constitutional Law, Essay in Honour of Andras Sajo, ed. Iulia Motoc, Paulo Pinto de Albuquerque, Krzystof Wojtyczek (Eleven International Publishing, 2018), 159-177.

24 Scheppele's term "autocratic legalism" is similar to Huq and Ginsburg's term "constitutional retrogression". Both view the destruction of democracy through constitutional mechanisms broadly, not only focusing on the processes of formal constitutional change. Unfortunately, Scheppele does not set a definite benchmark when introducing her term but merely defines "autocratic legalism" as the situation where an "electoral mandate plus constitutional and legal change are used in the service of an illiberal agenda". Scheppele, "Autocratic Legalism," 548.

25 Huq and Ginsburg, "How to Lose a Constitutional Democracy". 9. 
Furthermore, it is important to understand what distinguishes this phenomenon from the traditional threat to democracy. According to Huq and Ginsburg, the traditional threat, authoritarian reversion, is characterized by the quick and complete destruction of the democratic order. This process usually occurs either through extra-constitutional actions, such as military coups against legitimate governments (as happened in Thailand, Mali, and Mauritania), or through the use of emergency power mechanisms (as happened in Weimar Germany and India under Prime Minister Indira Gandhi’s leadership). ${ }^{26}$

In contrast to authoritarian reversion, constitutional retrogression involves the incremental destruction of democracy under the cloak of the rule of law and the constitution. ${ }^{27}$ The democratic order does not directly collapse, but rather there is a gradual and continuous decline in the quality of the three main elements of democracy: the democratic electoral system, rights to speech and association, and the rule of law, which in combination over time has the same effect as authoritarian reversion..$^{28}$ It is also important to understand that "retrogression" only occurs when there is the systematic destruction of the three main elements of democracy rather than just one of them. It is only when the quality of all three elements decreases that democracy is endangered. ${ }^{29}$

Constitutional retrogression, according to Huq and Ginsburg, usually occurs in five steps: (1) a formal constitutional amendment that in substance marginalizes the opposition and removes presidential term limits ${ }^{3^{\circ}}$ (examples of the use of this mechanism can be seen in some Central African countries, such as Cameroon, Chad, and Gabon); ${ }^{31}$ (2) the elimination of institutional checks, as in Poland, when the Law and Justice Party won both the presidential and legislative elections in 2015, and enacted a new Law on the Constitutional Court, whose substance weakened the role of the Court in checking their power; ${ }^{32}$ (3)

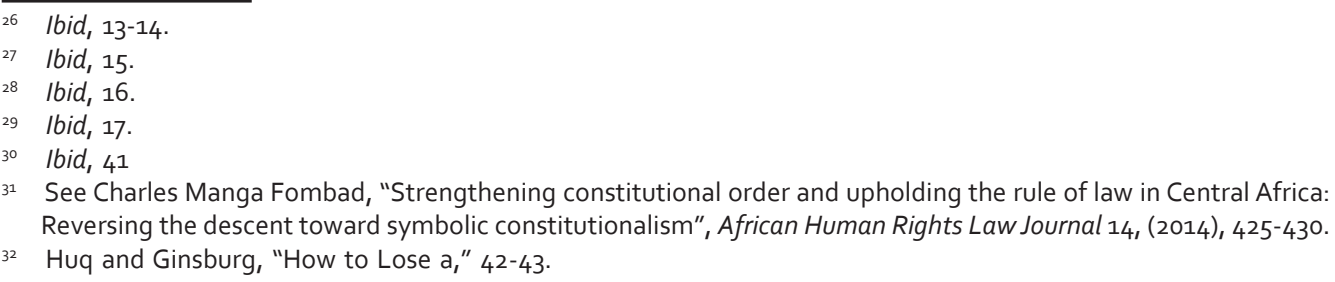


centralizing and politicizing executive power, as exemplified by President Erdogan in Turkey, who reformed the court system to give him greater control over the appointment of judges and prosecutors;33 (4) degrading the public sphere, usually through the enactment of a media law which allows the government to freely ban the press or by enacting a law on non-governmental organizations (NGOs), whose substance makes it easy for governments to dissolve an NGO or similar societal organizations; 34 and (5) the elimination of political competition, usually manifested by the actions of rulers in weakening the opposition (the best example of this is the Fidesz government in Hungary, which manipulates election laws to make it difficult for the opposition to compete). 35

The more specific phenomenon of democratic destruction through the mechanism of law and the constitution, on the other hand, as described by Landau, is closely related to the rise of populism. This connection arises because, over the past 20 years, many populist leaders have used constitutional provisions to undermine democracy after coming to power. ${ }^{36}$ The list includes President Alberto Fujimori in Peru (1995), Hugo Chavez in Venezuela (1999), Rafael Correa in Ecuador (2008), President Evo Morales in Bolivia (2009), Viktor Orban in Hungary (2011), and President Erdogan in Turkey. ${ }^{37}$

The reason why populist leaders tend to engage in constitutional retrogression is that their appeal depends on a dichotomy between "the people" whom they claim to represent and the "corrupt elite" that opposes them. Populist leaders thus generally claim to be outsiders of the political system who want to reform the economic and political structure by involving groups previously marginalized by corrupt elites.$^{38}$ They also claim that they are the only legitimate representatives of the people so that those who oppose them - the corrupt elite -have no right to compete with them in elections. ${ }^{39}$

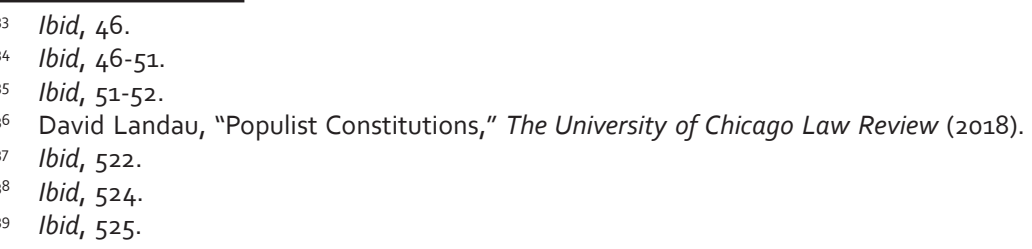


The belief that they are the sole legitimate representative of the people makes populist leaders dangerous to democracy. Based on this belief, they often criticize the existing constitutional order, which they allege has been utilized by corrupt elites to maintain themselves in power. That is why changing the law and the constitution is central to their political programme. ${ }^{40}$ When successful in changing the existing institutional order, for example through the constitutional amendment or constitutional replacement, populist rulers seek to monopolize the political process rather than seeking consensus with the opposition and elements of the old institutional order they perceive as corrupt. ${ }^{41}$ For example, in Venezuela and Ecuador, Presidents Chavez and Correa, after successfully changing the constitution, undertook steps such as formulating election laws that favoured their positions, dismissed judges who disobeyed them and dissolved the current legislature to ensure that its successor was under their control. In Hungary, Fidesz, after successfully taking control of the parliament, adopted a new constitution without involving the opposition. ${ }^{42}$

Populist leaders also tend to consolidate their power after acquiring it. They do so by strengthening the authority of the executive branch and eliminating term limits. ${ }^{43}$ They also often attack independent institutions that function to check their power, such as courts, media, tax authorities, and electoral commissions. Populist rulers fill these institutions with party loyalists so that they are no longer independent. ${ }^{44}$ The main target of such populist rulers is usually the Constitutional Court, since it is this institution, especially in countries that have undergone a transition from authoritarianism to democracy, that has the primary function of safeguarding democracy by protecting its own independence and the independence of other state institutions, and upholding human rights. ${ }^{45}$

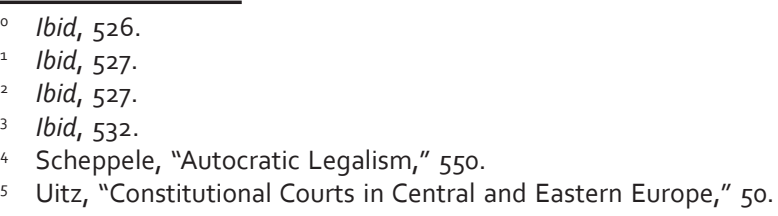




\subsection{Constitutional Retrogression in Indonesia: Worrying Indications}

When President Joko Widodo came to power in 2014, he was a weak president. At the time, $60 \%$ of the People's Representative Council (Dewan Perwakilan Rakyat or DPR $)^{46}$ was controlled by Prabowo Subianto, the opponent he narrowly defeated in the 2014 presidential elections. ${ }^{47}$ However, since then, Widodo has successfully consolidated his power. Currently, his coalition is supported by $67 \%$ of the DPR. He built this support by persuading the two main opposition parties to switch sides. ${ }^{4}$

Unfortunately, President Widodo's success in consolidating his power has been accompanied by worrying developments. One of the most prominent of these, according to human rights activists, involved his use of the Government Regulation in Lieu of Laws mechanism in the 1945 Constitution, which allows the President to enact a government regulation without requiring DPR approval in the face of "compelling exigencies".49 In 2017, Widodo used this mechanism to issue Government Regulation in Lieu of Laws 2 of 2017 on the Amendment of Law 17 of 2013 on Societal Organizations (hereinafter 'Perpu 2/2017'). This Regulation was subsequently approved by the DPR to become Law 16 of 2017 on the Stipulation of Government Regulation in Lieu of Law 2 of 2017 on Amendment of Law 17 of 2013 on Societal Organizations.50 The adoption of Perpu 2/2017 caused controversy because it threatened one of the fundamental elements of democracy, viz. rights to speech and association. In particular, the Perpu makes it easier for the government to dissolve an organization by eliminating the courts'

${ }_{46}$ The DPR is the lower house of the Indonesian Parliament. It has joint power with the President to make laws, which is why its support is important for Presidents to implement their agenda. See Article 20(2) of the 1945 Constitution, which provides: "Every bill shall be discussed by the People's Representative Council and the President in order to acquire joint approval."

47 Stefanus Hendrianto, "Indonesian Constitutional Conundrum: The Weak Presidency, the Strong Opposition and the Regional Election Law," Int'l J. Const. L. Blog (October 2014), http://www.iconnectblog.com/2014/og/ indonesias-constitutional-conundrum-the-weak-presidency-the-strong-opposition-and-the-regional-elections-law/.

48 Stefanus Hendrianto and Fritz Siregar, "Indonesia: Development in Indonesian Constitutional Law," in 2016 Global Review of Constitutional Law, ed. Richard Albert, David Landau, Pietro Faraguna and Simon Drugda, (Boston: ICONnect-Clough Center, 2017), 93.

49 See Art. 22(1) of the 1945 Constitution: "In the event of compelling exigency, the President is entitled to stipulate government regulations in lieu of laws."

50 Usman Hamid and Liam Gammon, "Jokowi Forges a Tool of Repression", New Mandala, 13 July 2017, http:// www.newmandala.org/jokowi-forges-tool-repression/ 
oversight role..$^{1}$ The Perpu also broadens the grounds on which an organization may be dissolved to include: $5^{2}$

- "using names, emblems, flags, or organizational symbols that have similarities, essentially or in part, with the names, emblems, flags, or organizational symbols of separatist movements or prohibited organizations" (paragraph 4 );

- "engaging in separatist activities that threaten the sovereignty of the Unitary State of the Republic of Indonesia” (paragraph 4b); and

- $\quad$ "following, spreading, and teaching doctrines or concepts which are contrary to Pancasila” (paragraph 4c).

The political context in which Joko Widodo's government enacted a Perpu that threatened rights to speech and association in this way was as follows. At the end of 2016 and the beginning of 2017, Widodo's government faced serious challenges in the form of the rise of political Islamist groups, who succeeded in overthrowing one of his key allies during the election of the DKI Jakarta governor, Basuki Tjahaja Purnama (popularly known as 'Ahok'). Faced with these challenges, and in order to minimize the threats posed by Islamist groups, the Widodo government dissolve Hizbut Tahrir Indonesia (HTI), one of the hardline Islamic organizations involved in the political Islamist movement, that have competing views with Indonesian national ideology of Pancasila. ${ }^{53}$ However, the aim to create this Perpu to dissolve HTI is unreasonable, because the mechanism for dissolving societal organization already exists in Law 17 of 2013 on Societal Organizations, even the mechanism in this law seems more democratic than in the Perpu, because it gives the court a chance to check first the government proposal to dissolve societal organizations. ${ }^{54}$

\footnotetext{
51 Article 71 of Law 17 of 2013 on Societal Organisation, which was amended by Perpu 2/2017, determines if the government's request to dissolve mass organizations must be decided first by the court.

52 Article 59 paragraph 4a,b,c Government Regulation in Lieu of Law 2 of 2017 Amending Law 17 of 2013 on Societal Organisations.

53 Giri Ahmad Taufik, "Proportionality Test in the 1945 Constitution: Limiting Hizbut Tahrir Freedom of Assembly," Constitutional Review 4, no. 1 (2018): 61.

54 Ibid, 68.
} 
Apart from issuing Perpu 2/2017, Widodo's government has also used another strategy to deal with the threat posed by the Islamist movement. This strategy takes the form of the criminal prosecution of Islamist movement leaders, mostly not in cases directly related to their activity in Islamist organizations or political demonstrations. ${ }^{55}$ The goal of this strategy is to limit their rights to speech and association. For example, one of the most prominent Islamist movement leaders, Rizieq Shihab, was investigated by the police for making an insulting remark about the official state ideology, Pancasila; for allegedly helping to spread pornographic images and texts; and on several other grounds. ${ }^{6}$ This strategy proved successful and Rizieq fled to Saudi Arabia. ${ }^{57}$ The problem with both Perpu 2/2017 and this strategy, however, is that, while countering the Islamist movement's populist and religious agenda, which undoubtedly threatens Indonesia's democracy, these responses themselves have undermined core political rights on which democracy depends.

Another action taken by Widodo's government that threatens rights to speech and association was Law 2 of 2018 on the Second Amendment of Law 17 of 2014 on the People's Consultative Assembly, People's Representative Assembly, Regional Representative Assembly and Regional People's Representative Assembly ('MD3 Law 2018'). This law threatens rights to speech, especially in Article 122, which authorizes the House Ethics Committee to take legal action against persons or groups that tarnish the dignity of the DPR..$^{8}$ The existence of this article very likely suppresses freedom of speech and criticism of the DPR, especially given the use of the vague term 'tarnish'.

The incorporation of this article in the $\mathrm{MD}_{3}$ Law may appear to relate more to the interests of the DPR than Joko Widodo's government. Widodo himself, in fact refused to sign the law after its adoption. Nevertheless, the original process of formulating the law required the joint agreement of the President and the

Mietzner, "Fighting Illiberalism with Illiberalism," 275.

Ibid.

Ibid, 276.

${ }^{8}$ Article 122 I of Law 2 of 2018 on the Second Amendment of Law 17 of 2014 on People's Consultative Assembly, People's Representative Council, Regional Representative Council, and Regional People's Representative Council, which stated that one of the tasks of the House Ethics Committee is "to take legal or other steps against individuals, groups or legal entities that tarnish the dignity of the DPR or its members." 
DPR.59 In addition, in instances where the President does not sign a law, the Constitution provides that the draft law will become law within 30 days, based on the President's approval in the formulation process. ${ }^{60}$ Moreover, the majority of the parties that voted to adopt the $\mathrm{MD}_{3}$ Law support the government, including the Indonesian Democratic Party of Struggle (PDIP), President Widodo's own party. ${ }^{61}$ Fortunately, as explained below, the sections of the $\mathrm{MD}_{3}$ Law that give the House Ethics Committee the power to bring actions against people or groups deemed to be tarnishing the dignity of the DPR were recently declared unconstitutional by the Constitutional Court. ${ }^{62}$

More recent evidence of the Widodo's government threat to rights to freedom of speech and association comes in the form of its attempt to repress a grassroots political opposition movement, the \#2019GantiPresiden (2019ChangePresident), by using police institutions backed by pro-government protesters. ${ }^{63}$ This move clearly violates rights to speech and association since the \#2019GantiPresiden movement is simply campaigning to change the Widodo administration in the 2019 elections rather than opposing democracy in the manner of HTI. The legitimacy of this movement has also been confirmed by the General Electoral Commission (Komisi Pemilihan Umum or KPU), the Electoral Oversight Agency (Badan Pengawas Pemilihan Umum or Bawaslu), and by NGOs committed to democratic pluralism. ${ }^{64}$

In addition to issuing regulations and acting in ways that threaten rights to speech and association, Joko Widodo's government has also engaged in activities that threaten another fundamental element of democracy, namely the need for

59 Stephen Sherlock, "Jokowi shares the blame for MD3 debacle," New Mandala, 19 March 2018, http://www. newmandala.org/jokowi-shares-blame-md3-debacle/.

60 See Article 20(5) of the 1945 Constitution: "In the event a bill having been jointly approved as such has failed validation by the President within a period of thirty days as of such bill has been approved, the bill as such shall lawfully become a law and shall be promulgated."

61 See Robertus Robet, "Beyond the bounds of democracy: DPR consolidates its power," Indonesia at Melbourne, February 23, 2018, http://indonesiaatmelbourne.unimelb.edu.au/beyond-the-bounds-of-democracy-dpr-seeksto-consolidate-its-power/.

62 Constitutional Court Decision Number 16/PUU-XVI/2018 on Judicial Review Law Number 2 Year 2018 on Second Amendment of Law Number 17 Year 2014 on People's Consultative Assembly, People's Representative Assembly, Regional Representative Assembly, and Regional People's Representative Assembly

${ }_{3}$ Tom Power, "Jokowi's authoritarian turn," New Mandala, accessed 15 October 2018, http://www.newmandala. org/jokowis-authoritarian-turn/.

64 lbid. 
a democratic electoral system. In many countries experiencing constitutional retrogression, it is common for rulers to maintain elections as an outward sign of support for democracy, but in reality to manipulate elections in a way that means that they are not truly democratic. ${ }^{65}$ In Indonesia, Widodo's government, with the support of a majority of the DPR, enacted Law 7 of 2017 on General Elections that requires candidates for President and Vice President to be proposed by political parties or coalitions of political parties that command at least $20 \%$ of the seats in the DPR or which received a minimum of $25 \%$ of the votes in the general elections ('presidential thresholds'). ${ }^{66}$ In defence of this measure, Widodo's government argued that the presidential threshold mechanism was needed to reduce the number of parties, so that Indonesia's presidential system would become more stable. ${ }^{67}$

The presidential threshold mechanism, however, limits the opposition's ability to compete in the presidential elections considering that almost $67 \%$ of the seats in the DPR are controlled by Widodo's government. In addition, when viewed from the perspective of the electoral system, this policy is an anomaly because Indonesia will hold simultaneous presidential and parliamentary elections in 2019 for the first time. This means that the 2019 results cannot be used to determine the $20 \%$ presidential threshold for nominating the President. ${ }^{68}$ Rather, the only way this mechanism can be implemented is to use the results of the previous legislative elections in 2014. Since the constellation of DPR members will definitely change after the 2019 election, this effectively undermines democracy by limiting the field of presidential candidates to persons who enjoyed the support of established political parties in the last electoral cycle.

Another key element of a democratic state, the rule of law, has also not been free from threat by Widodo's government. The threat on this occasion consists of the weakening of law enforcement institutions. For example, the DPR has ordered

65 Kim Lane Scheppele, "Autocratic Legalism," 565-566.

66 See Article 222 Law Number 7 Year 2017 on General Election.

67 "Tjahjo: Presidential Treshold 20 Persen Bukan untuk Jegal Calon," Tempo.co, accessed 17 July 2018, https:// nasional.tempo.co/read/892072/tjahjo-presidential-threshold-20-persen-bukan-untuk-jegal-calon.

68 "Peneliti Perludem: UU Pemilu bisa Menyulitkan Jokowi Sendiri," Tirto, accessed 15 July 2018, https://tirto.id/ peneliti-perludem-uu-pemilu-bisa-menyulitkan-jokowi-sendiri-cs8g. 
an inquiry into the Corruption Eradication Commission (Komisi Pemberantasan Korupsi or KPK), the key institution created to achieve the reformasi objective of eradicating corruption. ${ }^{69}$ The pretext for the inquiry was the need to supervise the implementation of the KPK's mandate in enforcing the law, with the DPR arguing that there were indications that the KPK had not compelled with relevant statutory provisions. ${ }^{70}$ On closer examination, however, it emerged that several DPR members are facing so-called 'e-KTP' cases before the KPK. Many activists and legal experts thus consider that the inquiry is intended to disrupt the KPK's focus on handling these cases. ${ }^{71}$ Since the majority of parties in the DPR that supported the launching of the inquiry were supporters of Widodo's government, Widodo may be considered responsible for it. ${ }^{72}$

Other law enforcement institutions in Indonesia have also been affected. One of these institutions was the Constitutional Court, an institution which, as noted, is often the main target of populist leaders seeking to undermine liberal democracy. ${ }^{73}$ Since its establishment, the Constitutional Court has played a crucial role in maintaining democracy and building a culture of constitutionalism among lawmakers. ${ }^{74}$ The Court is thus certainly now one of the main barriers in the way of any Indonesian government that wants to consolidate its power.

The Widodo government's assault on the Court was admittedly less severe than in Poland, where a new law was enacted to allow for packing of the courts. ${ }^{75}$ In Indonesia's case, the attack took the form of the DPR's re-appointment of Justice Arief Hidayat to a second term. Hidayat's re-appointment was controversial

69 "Agar Reformasi Pemberantasan Korupsi Tidak Sebatas Ekspektasi," Transparency International Indonesia, accessed 16 July 2018, http://ti.or.id/refleksi-gerakan-antikorupsi-menjawab-tantangan-20-tahun-reformasi/.

70 "DPR Setuju Gunakan Hak Angket terhadap KPK," Tirto, accessed 16 July 2018, https://tirto.id/dpr-setuju-gunakanhak-angket-terhadap-kpk-cnBr.

71 "KPK: Hak Angket Tak Akan Hentikan Pengusutan Kasus e-KTP," Tirto, accessed 16 July 2018, https://tirto.id/ kpk-hak-angket-tak-akan-hentikan-pengusutan-kasus-e-ktp-cnDY.

72 Ihsanuddin, "Pansus KPK Diisi Fraksi Pendukung Pemerintah, Jokowi Diminta Bersikap," Kompas.com, accessed 16 July 2018, https://nasional.kompas.com/read/2017/07/25/12451401/pansus-kpk-diisi-fraksi-pendukung-pemerintahjokowi-diminta-bersikap.

73 Scheppele, "Autocratic Legalism," 550-553.

74 Simon Butt, "Indonesia's Constitutional Court: Conservative activist or strategic operator?" in The Judicialization of Politics in Asia, ed. Bjoern Dressel, (London and New York: Routledge, 2012), 111.

75 The weakening of the Constitutional Court in Poland was affected by the governing Law and Justice Party with amending the Constitutional Court Law, which allowed the addition of three new sympathetic judges. See Tom Gerald Daly, "Democratic Decay", 14. 
because before undergoing the required fit and proper test, he was suspected of meeting several members of the DPR's Commission III (the commission that focuses on law, human rights, and security issues), and particularly with members of the DPR who support the government. This meeting led to Hidayat's being investigated by the Constitutional Court's Ethics Council, which resulted in an ethical sanction in the form of a warning in mid-January 2018. ${ }^{76}$ Unfortunately, despite being proven to have met with members of the DPR and then accepting the ethical sanction, Hidayat was re-appointed as a Constitutional Court Justice by the DPR on March 27, 2018. The re-appointment was heavily criticized by the opposition and constitutional law scholars, who doubted its independence. ${ }^{77}$

Based on these examples, it can be said that Indonesia's democracy has undergone constitutional retrogression as defined. Widodo's government has systematically targeted all three fundamental elements which according to Huq and Ginsburg must exist in a democratic state, i.e. a democratic electoral system, rights to speech and association, and the rule of law. ${ }^{78}$ To be sure, when these attacks began, they were more ad hoc in nature, such as the criminalization of radical Islamic leaders and the use of Perpu 2/2017 to block the Islamist populist movement in the Jakarta Gubernatorial election. ${ }^{79}$ However, as time has progressed, the Widodo government has seen the advantages of these ad hoc measures, and deliberately expanded them to combat regular democratic opposition, as seen in the repression of the \#2019GantiPresiden movement.

The severity of the harm done by Widodo's government to democratic institutions has not been equivalent across all three elements. Rights to speech and association have thus experienced the most severe threats, especially after the DPR's approval of Perpu 2/2017 in the form of Law 16 of 2017. ${ }^{80}$ The

76 Fabian Januarius, "Terlibat Kasus-Kasus Etik, Arief Hidayat Diminta Mundur dari Ketua MK," Kompas.com, accessed 16 July 2018, https://nasional.kompas.com/read/2018/01/25/20110941/terlibat-kasus-kasus-etik-ariefhidayat-diminta-mundur-dari-ketua-mk.

77 "Pelantikan Arief Hidayat Wujud Penurunan Kualitas Hakim MK," Tirto, accessed 16 July 2018, https://tirto.id/ pelantikan-arief-hidayat-wujud-penurunan-kualitas-hakim-mk-cGOo.

78 Huq and Ginsburg, "How to Lose a," 9.

79 Tom Power, "Jokowi's authoritarian turn".

8o Some Indonesian constitutional law scholars criticized the issuing of this Perpu, arguing that the regulation was issued through a Perpu mechanism which did not involve the DPR, so it had an element of dictatorship. "Perpu Ormas Dinilai Batasi Hak Berserikat", Republika.co.id, accessed 17 July 2018, https://www.republika.co.id/berita/ nasional/politik/17/07/15/ot3mgy368-perppu-ormas-dinilai-batasi-hak-berserikat 
government's action in prosecuting certain opposition leaders and repressing grassroots opposition movements has also shown that rights to speech and association are in quite a precarious position. On the other hand, the electoral system and the rule of law, despite facing threats, have not yet been truly undermined, as evidenced by the existence of a vigorous opposition that will challenge Widodo's bid for a second term in the 2019 presidential elections. While the opposition's challenge has been complicated by the $20 \%$ presidential threshold requirement, ${ }^{81}$ this barrier is not insurmountable. There are also still indications that the Constitutional Court has been able to act independently, for example through its decision to overturn those parts of the MD3 Law that threaten rights to speech, and through its Ethics Council's decision to sanction Hidayat for meeting with the DPR. As things stand, only one of the Constitutional Court judges is considered not to be independent.

Apart from that, there are doubts about whether Widodo is himself a populist leader as understood in the literature on constitutional retrogression or whether he is a pragmatic politician who is trying to contain populist elements in the country. Marcus Mietzner, for his part, has argued that Widodo is a new or 'technocratic' populist ruler. ${ }^{82}$ According to this view, Widodo is different from traditional populist rulers, such as his arch-enemy, Prabowo Subianto. He acts inclusively rather than trying to exclude his political opponents; he is a nationalist like traditional populist leaders but does not use anti-foreign rhetoric in the same way they do; and, again like traditional populists, he criticizes the existing political elite, but wants to improve rather than replace them. ${ }^{83}$ In making these distinctions, Mietzner portrays Widodo's new form of populism as something positive for democracy. ${ }^{84}$

81 The existence of an opposition party that will challenge Joko Widodo is shown, for example, through the statement of Prabowo Subianto (Jokowi's opponent in the 2014 presidential election) of his readiness to confront Joko Widodo again in the 2019 presidential election at the Gerindra Rakornas (National Coordination Meeting). See Liam Gammon, "Prabowo didn't just announce a presidential run," New Mandala, accessed 18 July 2018, http:// www.newmandala.org/prabowo-didnt-just-announce-presidential-run/.

82 Marcus Mietzner, Reinventing Asian Populism: Jokowi's Rise, Democracy, and Political Contestation in Indonesia (Honolulu: East-West Center, 2015), 2-3.

$8_{3}$ Ibid. According to Howse, the good populist is not wanted for popular hegemony, in fact, the demand is to solve underinclusiveness and underrepresentation. See Rob Howse, "Populism and Its Enemies" (Workshop on Public Law and the New Populism, Jean Monnet Center, NYU Law School, 15-16 September 2017).

84 Ibid. 
Against this, however, it is clear that some elements of this new populism have undoubtedly threatened democracy. For example, when enacting Perpu 2/2017 and using it to dissolve HTI organizations that are opposed to democracy, ${ }^{85}$ Widodo justified his actions as necessary to safeguard the unity of the people in accordance with the inclusive Indonesian ideology of Pancasila. ${ }^{86}$ In substance, however, the Perpu is not really inclusive because it targets not only the enemies of democracy like HTI, but other groups, too, which are considered as having views that conflict with Pancasila principles, including atheists and Marxists. ${ }^{87}$

The Widodo government's use of Pancasila also reflects one of the characteristics that according to Luigi Corrias are commonly found in populist rulers, namely the habit of using constitutional identity as a shield for legitimizing their government. ${ }^{88}$ Pancasila in this case, can be regarded as the embodiment of Indonesia's constitutional identity. ${ }^{89}$ During his administration, Widodo has used Pancasila extensively, not only in Perpu 2/2017, but also in other legitimizing actions, for example by issuing slogans such as "saya Indonesia, saya Pancasila" ("I am Indonesia, I am Pancasila") and by forming a special body whose duty is to develop and foster Pancasila ideology in every element of society. This move represents the most extensive mobilization of the ideology of Pancasila by the Indonesian government since the fall of Soeharto. ${ }^{\circ}$

85 Giri, "Proportionality Test", 58-59.

86 "Jokowi: Perpu Ormas dibuat untuk menjaga Pancasila dan NKRI,", Tempo.co, accessed 19 July 2018, https:// nasional.tempo.co/read/1028012/jokowi-perpu-ormas-dibuat-untuk-menjaga-pancasila-dan-nkri.

${ }_{87}$ The substance of Perpu 2/2017 which excludes many groups can be seen in the official elucidation of Article 1(4C) Government Regulation in Lieu of Law 2 of 2017 Amending Law 17 of 2013 on Societal Organisations.

88 According to Corrias, populist ideas usually contain three implicit constitutional theories, that is the constituent power, popular sovereignty, and constitutional identity. See Luigi Corrias, "Populism in a Constitutional Key: Constituent Power, Popular Sovereignty and Constitutional Identity," European Constitutional Law Review 12, no. 1 (2016).

89 Pancasila is viewed by many Indonesians as an Indonesian ideology and identity, and many scholars from Indonesia and foreigners believe Pancasila contains values which are compatible with democracy like 'inclusivism' and 'pluralism'. However, a study by Pranoto Iskandar challenges this claim. His study shows that Pancasila contains the traditional communitarian spirit, which is not only biased towards a limited number of religions but could also potentially jeopardize democracy. See Pranoto Iskandar, "The Pancasila Delusion," Journal of Contemporary Asia 46, no. 4 (2016): 723-735; Populists, according to Corrias, often see constitutional identity as something fixed once and for all, pre-determined before the enactment of a legal order and stored away, untouchable by the ravages of time. Ibid, 22.

90 Soeharto used Pancasila propaganda (knowing as ' $\mathrm{P}_{4}$ ') in every element of the state to legitimize his authoritarian rule See Tim Lindsey, "Indonesia Devaluing Asian Values, Rewriting Rule of Law", in Asian Discourses of Rule of Law Theories and Implementation of Rule of Law in Twelve Asian Countries, France and the U.S, ed. Randall Peerenboom (London and New York: Routledge, 2004), 290. 
The Widodo government's tendency to exclude minority groups is also revealed by the draft of the New Penal Code (Rancangan Kitab Undang-Undang Hukum Pidana or RKUHP), which it has pushed hard to enact as soon as possible. The draft contains a controversial provision criminalizing homosexual activities. $^{91}$ Not only that, but Widodo's government has, as noted, also tried to insulate itself from the electoral competition by creating the presidential threshold mechanism, which is democratically questionable given the move to simultaneous presidential and parliamentary elections. These developments tend to support Tom Daly's caution against distinguishing 'good' and 'bad' forms of populism, ${ }^{92}$ as proposed by Rob Howse. ${ }^{93}$ Based on the Indonesian experience, it is clear that 'good' populists, whom Howse argues are less dangerous because of their pluralist and inclusivist character, can threaten democracy to the same degree as 'bad' populists.

In summary, while Widodo may not be a populist leader in the classical mould, his government's actions have weakened all three of the main support structures for democracy in Indonesia. The question accordingly arises whether there is anything that can be done to prevent and reverse this constitutional retrogression process, and in particular whether the Constitutional Court may play a role.

${ }_{91}$ Article 454 RKUHP, which regulates sexual abuse by same-sex persons. This article has been criticized by many human rights organization because the new penal code already contains a provision on sexual abuse. So the existence of a specific article about sexual abuse by same-sex persons is suspected of discriminating against the lesbian, gay, bisexual, and transgender (LGBT) community. See Anggara (et. al), Catatan dan Rekomendasi ICJR terhadap beberapa ketentuan dalam RKUHP (Jakarta: Institute for Criminal Justice Reform, 2018). Many statements by officials of Joko Widodo's government reveal that the government clearly rejects the LGBT community. For example, the Minister of Religion, Lukman Hakim Saifuddin, called on all Indonesians "to embrace [LGBT people] so they will be conscious that they live in a religious society which can't accept homosexuality." See Phelim Kine, "Indonesian Religion Minister's Contradictory LGBT 'Embrace'," Human Rights Watch, accessed 8 October 2018, https://www.hrw.org/news/2017/12/19/indonesian-religion-ministers-contradictory-lgbt-embrace.

92 Tom Gerald Daly, "Populism, Elitism and Democratic Decay in Brazil" (Paper presented at International Society of Public Law Conference, Hong Kong, 26 June, 2018), 4.

93 Rob Howse divides populists into two types. The first is the good populist who rails against elites. However, such claims are pluralist since they do not take the form of a demand for popular hegemony but are rather a critique of the underrepresentation of people in the political system that is dominated by elites. The second is the bad populist. This type of populist takes aim at minority rights. They will engage in actions such as arbitrary seizure or nationalization of the property of elites, punitive taxes, deportation of foreign workers, and many more. See Rob Howse, "Populism and Its Enemies", 3. 


\subsection{Can the Constitutional Court arrest the slide?}

A country's constitutional court is often the main target of populist rulers intent on orchestrating constitutional retrogression. The obvious reason for this is that democratic states, especially those that have just emerged from a long period of authoritarianism, such as Indonesia, establish constitutional courts with the specific purpose of safeguarding democracy from attack. ${ }^{94}$

In the Indonesian case, one of the positive aspects of the constitutional retrogression process that has occurred is that the Constitutional Court has thus far not been captured. As we have seen, the Widodo government and its supporting parties succeeded in extending Justice Arief Hidayat's term of office. However, this success was a turning point for the Constitutional Court. After Hidayat's controversial re-appointment, a public petition was signed questioning his neutrality. ${ }^{95}$ While Hidayat refused to resign, the petition played a role in ensuring that he was not re-elected by his fellow justices to the position of Chief Justice.

Hidayat's failure to resume the Chief Justiceship shows that the amended 1945 Constitution, which divides the appointment of Constitutional Court justices between three institutions (the President, the DPR and the Supreme Court (Mahkamah Agung or MA), has made it difficult for Widodo's government to pack the Constitutional Court. ${ }^{6}$ Even though it succeeded in controlling one constitutional justice, there were still eight other constitutional justices with sufficient independence to resist the attack. At the same time, the success of the

94 Hamdan Zoelva, "Negara Hukum dan Demokrasi: Peran Mahkamah Konstitusi Menegakkan Hukum dan Demokrasi," in Negara Hukum yang Berkeadilan, ed. Susi Dwi Harijanti et. al, (Bandung: Pusat Studi Kebijakan Negara Fakultas Hukum Universitas Padjadjaran, 2011), 625; See also Katherine Glenn Bass and Sujit Choudry, "Constitutional Review in New Democracies," The Center for Constitutional Transitions at NYU Law Briefing Paper 40, September 2013.

95 See the Petition "Save the Constitutional Court, Arief Hidayat Must Resign", which was signed by around 16,000 people. This petition was drafted shortly after the inauguration of Arief Hidayat. https://www.change.org/p/ selamatkan-mk

96 Article ${ }_{24} \mathrm{C}(1)$ of the 1945 Constitution: "The Constitutional Court shall have nine members to be designated by the President, respectively three people to be proposed by the Supreme Court, three people by the People's Representative Council, and three people by the President." 
Hidayat petition shows the importance of public support to the Constitutional Court's ability to protect its independence. ${ }^{97}$

The Constitutional Court also demonstrated its independence in the MD3 Law case, which, as we have seen involved a challenge to provisions giving the DPR's House Ethics Committee the authority to take legal action against people or groups who tarnish its reputation. ${ }^{98}$ In this case, the Constitutional Court, despite the presence on the Bench of a judge whose independence had been called into question, proved its neutrality by striking the impugned provisions down.

In other instances, the Constitutional Court has been less effective in resisting the Widodo government's efforts to weaken democracy by. For example, on two different cases in 2017 and 2018, the Court declined to annul the $20 \%$ presidential threshold mechanism in Law 7 of 2017 on General Elections, ${ }^{99}$ even though the use of such a threshold in combination with simultaneous presidential and parliamentary elections is not common. Nevertheless, there are other opportunities for the Constitutional Court to intervene in defence of democracy, specifically in the case of Perpu 2/2017 which was approved by the DPR in Law 16 Year 2017, and is currently under review by the Court.

Whether the Constitutional Court will be able to stop the constitutional retrogression process in Indonesia from getting worse depends in part on the changing political context. As Stephen Gardbaum has argued, all other things being equal, it is the political context that determines whether a constitutional tribunal with the requisite formal powers to prevent government attempts to destroy democracy actually will intervene to do so. ${ }^{100}$ By political context, Gardbaum means such things as the outcome of an election that influences the appointment of constitutional tribunal judges or shifts in public opinion

97 The Indonesian Constitutional Court's tendency to annul laws correlates to the strength of public support in favour of annulment. See Dominic Nardi, "Indonesia's Constitutional Court and Public Opinion," New Mandala, accessed 23 July 2018, http://www.newmandala.org/indonesias-constitutional-court-public-opinion/parties.

98 See Constitutional Court Decision Number 16/PUU-XVI/2018.

99 See Constitutional Court Decision Number 53/PUU-XV/2017 on Judicial Review of Law Number 7 Year 2017 on General Election; See also Marguerita Afra Sapiie, "Constitutional Court maintains presidential threshold", Jakarta Post, accessed o5 December 2018, http://www.thejakartapost.com/news/2018/10/25/constitutional-courtmaintains-presidential-threshold.html

100 Stephen Gardbaum, "What Makes for More or Less Powerful Constitutional Courts?" UCLA School of Law, Public Law \& Legal Theory Research Paper, no. 17-37 (2017). 
that affects the extent of public support for a democracy-protecting outcome. ${ }^{101}$ In Indonesia's case, the amended 1945 Constitution undoubtedly gives the Constitutional Court sufficiently strong authority to protect democracy. The judicial appointment process has thus far also not been too severely compromised. Thus, if Gardbaum is right, much will depend on public support.

The events surrounding Hidayat's failed attempt to reoccupy the position of Chief Justice already provide some evidence that public opinion indeed plays an important role for the Constitutional Court. This point has further been acknowledged by one of the former justices of the Court, Maruarar Siahaan. According to Siahaan, public opinion and NGO's (Non-Governmental Organizations) are important sources of support for the Court. His exact words were: "Public opinion has been very kind to the Court". ${ }^{102}$ Similarly, the media, in Siahaan's view, are vital to the effort to defend the Court's independence. While the Court has sometimes allowed public pressure to influence its decisions, the media and public opinion are effective weapons to protect the Court from intervention by political elites. ${ }^{103}$ In addition to this anecdotal evidence, Dominic Nardi's statistical study shows that the more NGOs and public opinion support the annulment of a law, the greater the chances of the Court's annulling it. ${ }^{104}$

There is also comparative support for this view. In 2002, Colombia was led by President Alvaro Uribe, a right-wing populist. ${ }^{105}$ The Colombian Constitution stipulated that the President could only serve for one term (four years in office), and afterward could not be re-elected. However, after completing his first term of office, Uribe succeeded in passing a constitutional amendment permitting the President to serve for two terms. The Colombian Constitutional Court reviewed this amendment, both in terms of substance and procedure, but refused to annul it. However, after the end of his second term of office approached, Uribe

101 Ibid, 17-18.

102 See Marcus Mietzner, "Political Conflict Resolution", 414.

103 Ibid.

104 Nardi, "Indonesia's Constitutional Court".

105 Jennifer Cyr and Carlos Melendez, "Colombia's right-wing populist movement defeated the peace deal. Here's what we know", The Washington Post, accessed 26 July 2018, https://www.washingtonpost.com/news/ monkey-cage/wp/2016/10/04/colombias-right-wing-populist-movement-defeated-the-peace-deal-heres-how-weknow/?utm_term=.obo442b7f46e. 
submitted another amendment to allow the President to serve for three terms. This time the Court declared the amendment unconstitutional, ${ }^{106}$ holding that Presidents who serve too long pose a danger to democracy because of their ability to appoint loyal officials to institutions that are meant to act as a check and balance on their authority. ${ }^{107}$

The Colombian example shows how a constitutional court can play an important role in preventing constitutional retrogression from getting worse. However, it should be noted that the success of the Colombian Constitutional Court in slowing the pace of democratic decay did not emerge from nothing. Rather, its success was based on a long history of strong public support. ${ }^{108}$ The Court in fact, took active steps to build its support during President Uribe's government, realizing that this would be necessary to allow it to play a democracyprotecting role. This support in the end, proved crucial in persuading President Uribe to think twice about disobeying the Court's decision, even though it was controversial in the sense that it overturned a duly enacted constitutional amendment. ${ }^{109}$

In Indonesia's case, the Constitutional Court has even greater prospects of preventing constitutional retrogression from getting worse because the attempts to undermine democracy in Indonesia are arguably not as bad as was the case in Colombia. In Indonesia, Joko Widodo's government's efforts to harm democracy are still being carried out through ordinary legislation, over which the Constitutional Court has supervisory authority. Unlike Colombia, where the Uribe government's attempts to undermine democracy were carried out through a constitutional amendment, ${ }^{110}$ the Indonesian Constitutional Court thus does not have to push the limits of its authority in order to protect the democratic system. It can do so by exercising its regular power of constitutional review.

\footnotetext{
${ }_{106}$ Rosalind Dixon and David Landau, "Transnational Constitutionalism and Limited Doctrine of Unconstitutional Constitutional Amendment," International Journal of Constitutional Law 13, no. 3 (2015): 616.

107 Ibid, 617.

108 Ibid.

109 Jorge Gonzalez Jacome, "In Defense of Judicial Populism: Lessons from Colombia," Verfassungblog, accessed 27 July 2018, https://verfassungsblog.de/in-defense-of-judicial-populism-lessons-from-colombia/.

${ }_{110}$ See Carlos Bernal, "Unconstitutional Constitutional Amendment in the Case Study of Colombia: An Analysis of the Justification and Meaning of the Constitutional Replacement Doctrine," International Journal of Constitutional Law 11, no. 2 (2013).
} 
However, the Indonesian Constitutional Court will not be able to defend democracy on its own against the Widodo's government's attempt to consolidate its power. As exemplified in Colombia, the Court will need broad public support. Constitutional law scholars and democratic activists can assist the Court in this respect by mobilizing public opinion in favour of the Court's efforts to stop the weakening of democracy. ${ }^{\text {II }}$ When lawyers support the Court judgments, it becomes harder for the executive to disobey them. ${ }^{112}$ The Indonesian Constitutional Court should also be able to attract public support by showing the public that the justices are independent and immune to bribery. The Court should also resume the strategies previously used under Chief Justices Jimly Asshiddiqie and Mahfud MD. Both Jimly and Mahfud MD frequently gave interviews and explained their decisions to the media with the intention of gaining public support while also forcing the institutions affected by their decisions to obey them. This strategy seems political, but as Stefanus Hendrianto's study shows, it proved to be a successful way of building the Constitutional Court's public support, so that the Court in the days of Jimly and Mahfud's leadership was able to assert its authority against political institutions such as the DPR and the President. ${ }^{113}$

\section{CONCLUSION}

This paper has revealed worrying signs that the phenomenon of constitutional retrogression has occurred in Indonesia. This is evident from the actions of Joko Widodo's government in harming the three fundamental elements of democracy, namely (1) democratic electoral system; (2) rights to speech and association; and (3) the integrity of law and legal institutions, i.e., the rule of law. While the weakening of democracy that has occurred does not justify labelling Joko Widodo's government an authoritarian regime, certain actions that the government has taken are clearly dangerous for democracy.

${ }_{111}$ Nardi, "Indonesia's Constitutional Court".

112 See Rosalind Dixon, "Living to Fight Another Day: Judicial Deferral in Defense of Democracy," Wisconsin Law Review 683 (2016): 696.

113 Stefanus Hendrianto, "The Rise and Fall of Heroic Chief Justices: Constitutional Politics and Judicial Leadership in Indonesia", Washington International Law Journal 25, no. 3 (June 2016). 
The importance of this finding is that it contradicts the view in the literature that certain kinds of populist leader are not truly threatening to democracy. Some scholars have thus argued that Joko Widodo is a 'good' populist, who do not pose a real threat. On the contrary, this paper has shown, the four years of Widodo's government have seen a progressive weakening in democratic institutions similar to what has occurred when the 'bad' populist govern.

Finally, even though constitutional retrogression has occurred, this does not mean that there is no hope of saving democracy in Indonesia. The main reason for hope is that Widodo's government has not succeeded in taking control of the Constitutional Court. Currently, the Court is in the process of reviewing laws whose substance is related to the Widodo government's attempts to undermine one of the main elements of democracy, rights to speech and association. If the Court annuls these laws, it may help to slow down a democratic decline in Indonesia. The Court cannot save democracy on its own, however. It needs broad public support to protect its independence and to force the other branches of government, especially the President and the DPR, to obey his decisions.

\section{BIBLIOGRAPHY}

Anggara (Et. Al). Catatan dan Rekomendasi ICJR terhadap beberapa ketentuan dalam RKUHP. Jakarta: Institute for Criminal Justice Reform, 2018.

Aspinall, Edward. "Twenty Years of Indonesian Democracy - How Many More?" New Mandala. Accessed 24 May 2018, http://www.newmandala.org/20-yearsreformasi/.

Bass, Katherine Glenn, and Sujit Choudry. "Constitutional Review in New Democracies." The Center for Constitutional Transitions at NYU Law Briefing Paper 40, September 2013.

Bernal, Carlos. "Unconstitutional Constitutional Amendment in the Case Study of Colombia: An Analysis of the Justification and Meaning of the Constitutional Replacement Doctrine." International Journal of Constitutional Law 11, no. 2 (2013). 
Butt, Simon. "Indonesia's Constitutional Court: Conservative activist or strategic operator?" in The Judicialization of Politics in Asia, edited by Bjoern Dressel, 98-116. London and New York: Routledge, 2012.

Cyr, Jennifer, and Carlos Melendez. "Colombia's right-wing populist movement defeated the peace deal. Here's we know." The Washington Post, accessed 26 July 2018. https://www.washingtonpost.com/news/monkey-cage/ $\mathrm{wp} / 2016 / 10 / 04 /$ colombias-right-wing-populist-movement-defeated-the-peacedeal-heres-how-we-know/?utm_term=.obo442b7f46e.

Constitutional Court Decision on Judicial Review Law on People's Consultative Assembly, People's Representative Assembly, Regional Representative Assembly, and Regional People's Representative Assembly, Number 16/ PUU-XVI/2018 (The Constitutional Court of the Republic of Indonesia, Law Number 2 Year 2018 on Second Amendment of Law Number 17 Year 2014). Constitutional Court Decision on Judicial Review Law on General Election, Number 53/PUU-XV/2017 (The Constitutional Court of the Republic of Indonesia, Law Number 7 Year 2017).

Corrias, Luigi. "Populism in a Constitutional Key: Constituent Power, Popular Sovereignty and Constitutional Identity." European Constitutional Law Review 12, no. 1 (2016).

Daly, Tom Gerald. “Democratic Decay in 2016." In Annual Review of Constitution-

Building Processes: 2016, edited by International IDEA, 7-23. Stockholm: International IDEA, 2017.

. "Populism, Elitism and Democratic Decay in Brazil." Paper Presented at International Society of Public Law Conference, Hong Kong, 26 June 2018. Rosalind Dixon. "Living to Fight Another Day: Judicial Deferral in Defense of Democracy." Wisconsin Law Review 683 (2016), 696.

Doctrine of Unconstitutional Constitutional Amendment.” International Journal of Constitutional Law 13, no. 3 (2015). 
Fombad, Charles Manga. "Strengthening constitutional order and upholding the rule of law in Central Africa: Reversing the descent toward symbolic constitutionalism." African Human Rights Law Journal 14, (2014).

Freedom House. "Freedom in the World 2018 Democracy in Crisis." Accessed 3 July 2018, https://freedomhouse.org/report/freedom-world/freedom-world-2018.

Gammon, Liam. "Prabowo didn't just announce a presidential run." New Mandala. Accessed 18 July 2018, http://www.newmandala.org/prabowo-didnt-justannounce-presidential-run/.

Gardbaum, Stephen. "What Makes for More or Less Powerful Constitutional Courts?" UCLA School of Law, Public Law E Legal Theory Research Paper, no. 17-37 (2017).

Government Regulation in Lieu Law Number 2 Year 2017 Amendment of Law Number 17 Year 2013 on Societal Organisation (Republic of Indonesia).

Grimm, Dieter. "How can a democratic constitution survive an autocratic majority?" Verfassungblog. Accessed 14 December 2018, https://verfassungsblog.de/howcan-a-democratic-constitution-survive-an-autocratic-majority/

Hamid, Usman, and Liam Gammon. "Jokowi Forges a Tool of Repression." New Mandala, 13 July 2017. http://www.newmandala.org/jokowi-forges-toolrepression/.

Halmai, Gabor. "Second Grade Constitutionalism? Hungary and Poland: How the EU Can and Should Cope with Illiberal Member States." In Developments in Constitutional Law, Essay in Honour of Andras Sajo, edited by Iulia Motoc, Paulo Pinto de Albuquerque, Krzystof Wojtyczek, 159-177. Eleven International Publishing, 2018.

Harijanti, Susi Dwi, and Tim Lindsey. "Indonesian General election test the amended Constitution and the new Constitutional Court." International Journal of Constitutional Law 4, no. 1 (2006): 138.

Hendrianto, Stefanus. "The Rise and Fall of Historic Chief Justices: Constitutional Politics and Judicial Leadership in Indonesia." Washington International Law Journal 25, no. 3 (June 2016). 
--------. "Indonesian Constitutional Conundrum: The Weak Presidency, the Strong Opposition and the Regional Election Law." Int'l J. Const. L. Blog (Oct 2014). http://www.iconnectblog.com/2014/og/indonesias-constitutionalconundrum-the-weak-presidency-the-strong-opposition-and-the-regionalelections-law/.

, and Fritz Siregar. "Indonesia: Development in Indonesian Constitutional Law". In 2016 Global Review of Constitutional Law, edited by Richard Albert, David Landau, Pietro Faraguna and Simon Drugda, 93-97. Boston: ICONnectClough Center, 2017.

Howse, Rob. "Populism and Its Enemies." Workshop on Public Law and the New Populism, Jean Monnet Center, NYU Law School, 15-16 September 2017.

Huq, Aziz, and Tom Ginsburg. "How to Lose a Constitutional Democracy." UCLA Law Review 65 (forthcoming 2018).

Ihsanuddin. "Pansus KPK Diisi Fraksi Pendukung Pemerintah, Jokowi Diminta Bersikap." Kompas.com, accessed 16 July, 2018. https://nasional.kompas.com/ $\mathrm{read} / 2017 / 07 / 25 / 12451401 /$ pansus-kpk-diisi-fraksi-pendukung-pemerintahjokowi-diminta-bersikap.

Iskandar, Pranoto. “The Pancasila Delusion." Journal of Contemporary Asia 46, no. 4 (2016).

Indonesia 1945 Constitution.

Jacome, Jorge Gonzalez. "In Defense of Judicial Populism: Lessons from Colombia." Verfassungblog. Accessed 27 July 2018. https://verfassungsblog.de/in-defenseof-judicial-populism-lessons-from-colombia/.

Januarius, Fabian. “Terlibat Kasus-Kasus Etik, Arief Hidayat Diminta Mundur dari Ketua MK." Kompas.com, accessed 16 July 2018. https://nasional.kompas.com/ $\mathrm{read} / 2018 / 01 / 25 / 20110941 /$ terlibat-kasus-kasus-etik-arief-hidayat-dimintamundur-dari-ketua-mk.

Kine, Phelim. "Indonesian Religion Minister's Contradictory LGBT 'Embrace." Human Rights Watch. Accessed 8 October 2018. https://www.hrw.org/ news/2017/12/19/indonesian-religion-ministers-contradictory-lgbt-embrace. 
Landau, David. “Abusive Constitutionalism." UC Davis Law Review 189 (2013).

--------. "Populist Constitutions." The University of Chicago Law Review 85 (2018).

Law Number 2 Year 2018 on Second Amendment of Law Number 17 Year 2014 on People's Consultative Assembly, People's Representative Council, Regional Representative Council, and Regional People's Representative Council (Republic of Indonesia).

Law Number 7 Year 2017 on General Election (Republic of Indonesia).

Law Number 17 Year 2013 on Societal Organisation (Republic of Indonesia).

Law Number 24 Year 2003 on The Constitutional Court (Republic of Indonesia).

Lindsey, Tim. "Indonesia Devaluing Asian values, rewriting rule of law." In Asian Discourses of Rule of Law: Theories and implementation of rule of law in twelve Asian countries France and the U.S, edited by Randall Peerenboom, 290. London and New York: Routledge, 2004.

Mietzner, Marcus. "Political Conflict Resolution and Democratic Consolidation in Indonesia: The Role of the Constitutional Court." Journal of East Asian Studies 10 (2010).

Reinventing Asian Populism: Jokowi's Rise, Democracy, and Political Contestation in Indonesia. Honolulu: East-West Center, 2015.

. "Fighting Illiberalism with Illiberalism: Islamic Populist and Democratic Deconsolidation in Indonesia." Pacific Affairs 21, no. 2, June (2018).

Nardi, Dominic. "Indonesia's Constitutional Court and Public Opinion." New Mandala, accessed 23 July 2018. http://www.newmandala.org/indonesiasconstitutional-court-public-opinion/.

Power, Tom. "Jokowi's authoritarian turn." New Mandala, accessed 15 October 2019. http://www.newmandala.org/jokowis-authoritarian-turn/

Robet, Robertus. "Beyond the bounds of democracy: DPR consolidates its power." Indonesia at Melbourne, February 23 2018. http://indonesiaatmelbourne. unimelb.edu.au/beyond-the-bounds-of-democracy-dpr-seeks-to-consolidateits-power/. 
Sapiie, Marguerita Afra. "Constitutional Court maintains presidential threshold." Jakarta Post, accessed o5 December 2018. http://www.thejakartapost.com/ news/2018/10/25/constitutional-court-maintains-presidential-threshold.html.

Scheppele, Kim Lane. "Autocratic Legalism." The University of Chicago Law Review 85 (2018).

---------. "Democracy by Judiciary. Or, why Courts Can be More Democratic than Parliaments." In Rethinking the Rule of Law after Communism, edited by Adam Czarnota, Martin Krygier and Wojciech Sadurski, 25-6o. Budapest: Central European University Press, 2005.

Sherlock, Stephen. "Jokowi shares the blame for MD3 debacle." New Mandala, 19 March 2018. http://www.newmandala.org/jokowi-shares-blame-md3-debacle/. Taufik, Giri Ahmad. "Proportionality Test in the 1945 Constitution: Limiting Hizbut Tahrir Freedom of Assembly." Constitutional Review 4, no. 1 (2018).

Tempo.co. "Jokowi: Perpu Ormas dibuat untuk menjaga Pancasila dan NKRI." Accessed 19 July 2018. https://nasional.tempo.co/read/1028012/jokowi-perpuormas-dibuat-untuk-menjaga-pancasila-dan-nkri.

Tempo.co. "Tjahjo: Presidential Treshold 20 Persen Bukan untuk Jegal Calon." Accessed 17 July 2018. https://nasional.tempo.co/read/892072/tjahjopresidential-threshold-2o-persen-bukan-untuk-jegal-calon

The Economist. “The Economist Intelligence Unit's Democracy Index." Accessed 5 July 2018. https://infographics.economist.com/2018/DemocracyIndex/.

Tirto. "Peluang Rocky Gerung cs Menangkan Uji Materi di MK.” Accessed 24 July 2018. https://tirto.id/peluang-rocky-gerung-cs-menangkan-uji-materipresidential-threshold-cMlv.

Tirto. "Pelantikan Arief Hidayat Wujud Penurunan Kualitas Hakim MK." Accessed 16 July 2018, https://tirto.id/pelantikan-arief-hidayat-wujud-penurunankualitas-hakim-mk-cGQo. 
Tirto. “KPK: Hak Angket Tak Akan Hentikan Pengusutan Kasus e-KTP.” Accessed 16 July 2018, https://tirto.id/kpk-hak-angket-tak-akan-hentikan-pengusutankasus-e-ktp-cnDY.

Tirto. “DPR Setuju Gunakan Hak Angket terhadap KPK.” Accessed 16 July 2018, https://tirto.id/dpr-setuju-gunakan-hak-angket-terhadap-kpk-cnBr.

Tirto. "Peneliti Perludem: UU Pemilu bisa Menyulitkan Jokowi Sendiri." Accessed 15 July 2018, https://tirto.id/peneliti-perludem-uu-pemilu-bisa-menyulitkanjokowi-sendiri-cs89.

Transparency International Indonesia. "Agar Reformasi Pemberantasan Korupsi Tidak Sebatas Ekspektasi.” Accessed 16 July 2018. http://ti.or.id/refleksigerakan-antikorupsi-menjawab-tantangan-2o-tahun-reformasi/.

Uitz, Renata. "Constitutional Courts in Central and Eastern Europe: What Makes a Question too Political?” Juridica International XIII (2007).

Varol, Ozan. "Stealth Authoritarianism." Iowa Law Review 100 (2015).

Zoelva, Hamdan. "Negara Hukum dan Demokrasi: Peran Mahkamah Konstitusi Menegakkan Hukum dan Demokrasi." In Negara Hukum yang Berkeadilan, edited by Susi Dwi Harijanti et. al, 622-65o. Bandung: Pusat Studi Kebijakan Negara Fakultas Hukum Universitas Padjadjaran, 2011. 